\title{
The Maqāma Genre and the History of an Islamicate Literary Form
}

\author{
Maurice Pomerantz \\ Program Head of Arab Crossroads Studies and Associate Professor \\ of Literature, Division of Arts and Humanities, New York University, \\ Abu Dhabi, United Arab Emirates \\ mp147@nyu.edu \\ Jonathan Decter \\ Edmond J. Safra Professor of Sephardic Studies, Department of Near Eastern \\ and Judaic Studies, Brandeis University, Waltham, MA, USA \\ decter@brandeis.edu
}

This issue of the Intellectual History of the Islamicate World is the first to be devoted to a particular literary genre, the maqäma. The maqāma is a form of narrative prose fiction invented in the fourth/tenth century by Badī' al-Zamān al-Hamadānī (d. 398/10o8). These short tales recount the exploits of characters as they travel throughout the cities of Syria, Iran, and Iraq, often engaging in physical disguise and linguistic trickery. The refined form of language and the spirit of wordplay reflect the shared erudite Arabic literary culture of Islamicate $a d a b$.

The topic of this special issue may seem surprising to some readers. Should this subject not belong more properly to one of the many journals that deal with Middle Eastern Literatures past and present? How is the travel of a literary form such as the maqāma worthy of interest within the larger frame of intellectual history? What is "intellectual" about a phenomenon that appears to be so intimately tied up with what might first be dismissed as the narrow concerns of belles-lettres and aesthetics? What might intellectual historians gain from studying the formal features of texts?

The editors of this volume maintain that the travel of literary form is an integral part of the intellectual history of the Islamicate World. The history of the maqāma considered in this volume begins in the fourth/tenth century in Central Asia and quickly ranges across many regions of the Muslim world including West Africa, North Africa, Egypt, the Levant, Iraq, Iran, Yemen and 
South and Southeast Asia. Similarly, the maqāma's travel across linguistic and confessional divides, in Persian and Hebrew, affords other parallel lines of inquiry. Further, the maqama plays a vital role in the history of literary modernism in the Middle East; nineteenth-century Arab authors such as Ahmad Fāris al-Šidyāq (d. 1887) and Muhammad al-Muwayliḥi (d. 1930) understood the maqāma as a central feature of the Arabic literary heritage.

The study of the origins, development, and subsequent travel of genre have long been a key area of inquiry in literary studies. Research on the novel yielded much fruit for historians considering the wide scale changes not only in the poetics of narrative over the longue durée in the history of European literatures and indeed the sense of Europe itself, but also for historians interested in questions of individual agency, enlightenment rationalism, the study of gender. Might the same not be true for more nuanced studies of the travel and transformation of the maqāma as a literary form?

For readers of this journal, the study of the maqaima might illumine some central questions concerning the category of the "Islamicate". Marshall Hodgson (d. 1968), who coined the term Islamicate, considered aesthetics as central to his understanding of its meaning:

the adjectival ending on the analogy of 'Italianate', 'in the Italian style', which refers not to Italy itself, not to just whatever is to be called properly Italian, but to something associated typically with Italian style and manner. One speaks of 'Italianate' architecture even in England or Turkey. ${ }^{1}$

For Hodgson, the Islamicate was something that could be experienced as an aesthetic category, a cultural style, or an artistic manner. Hodgson's discussion of cultural aesthetics presumes a cluster of formal elements that could be reproduced and adapted to different locations like Italianate architecture. His aim was to distance himself from the Orientalist idea that cultural patterns were direct products of a common religious origin or essence. The term Islamicate thus allows for an appreciation of shared cultural patterns across religious traditions.

Although the maqāma and its peregrinations might be understood within the broader framework of Islamicate literary aesthetics, the unit of analysis for many of the contributions to this volume will be literary form. Caroline Levine's recent monograph Forms: Whole Rhythm Hierarchy Network suggests that liter-

1 Marshall G.S. Hodgson, The Venture of Islam: Conscience and History in a World Civilization, Chicago: University of Chicago Press, 1977, vol. 1, p. 59. 
ary form is never a static whole standing apart from a society. ${ }^{2}$ For Levine, the discussion of form must always be considered within a larger social context. Thus, questions of the genesis, circulation, reception, adaptation, reading, and commentary are all central to the study of the maqāma, and several contributions to this volume examine the maquama's relationship to Islamicate ideas, knowledge, and aesthetics.

What were the social formations and intellectual values that sustained the widespread writing and reading of the maqāma over time? How does adab and its discourses relate to the other intellectual disciplines such as history, philosophy, polemic, and the rational sciences? In what ways do the transformations of the maqāma in time, space, and language speak to particularly important "affordances" (a term Levine borrows from architecture for the potentialities latent in form) and how might they address broader questions of cultural continuity and change in Islamicate and world literary traditions? 3

This volume of seven studies offers valuable new avenues of research. They each reveal how diverse the particular literary products are even as they foreground broader questions of the travel of form and its meaning.

\section{$1 \quad$ Multiple Narrators of a Traveling Genre}

The classical form of the maqāma that al-Hamadānì devised was sufficiently simple to replicate, while at the same time it allowed space for much experimentation and innovation. The classical maqäma centers on the exploits of a cunning itinerant trickster named Abū l-Fath al-Iskandarī who survives by his fantastic wits and literary abilities. A central conceit of the form is that a fictional character named 'Īsā b. Hišām, who repeatedly encounters the trickster, relates these tales of Abū l-Fatḥ's exploits. Through the tales of 'Isā b. Hišām, readers are taken on a journey in which they encounter the trickster feigning blindness before a crowd in Ahwāz in the Makfüfiyya, or joining forces with the trickster-as-prophet as he tries to raise a man from the dead in the Mawșiliyya, or encountering the trickster posing as a madman in a hospital in the Maristāniyya.

Forms are perhaps best perceived when their boundaries are stretched and changed, and one can see that al-Hamadānī's own collection is far more heterogeneous than the above description might first suggest. In the self-referential

2 Caroline Levine, Forms: Whole, Rhythm, Hierarchy, Network, Princeton: Princeton University Press, 2015, p. 3.

3 See Levine, Forms, 6, for the particular use of the term, "affordances". 
and playful world of the maqāma, stable categories are few. The one inexhaustible resource however must be understood as the richness of the Arabic language, which is exploited at every turn by the playful trickster Abū l-Fath.

The meaning of the maqāma form must also be rooted in a deep understanding of the world of its readers and writers. Devin Stewart's article, "İsā b. Hišām's Shiism and Religious Polemic in the Maqāmāt of Badī' al-Zamān al-Hamadānī (d. 398/10o8)," attempts to situate al-Hamadānī's work within the intellectual context that produced it. Stewart focuses on the tenth-century courtly world in which discussion and debate of Sunni and Shiite polemics figured prominently $-\mathrm{a}$ feature that he claims has been "lost on later audiences". Stewart argues for the Sunnism of al-Hamadānī (pace James T. Monroe) through a careful reading of al-Hamadāni’s epistles (sources that have to this day been underutilized in the study of the Maqāmāt). Stewart goes beyond a simple and straightforward reading of the biography of al-Hamadānī to claim that the author's allegiances were central to certain compositional features of the Maqāmāt such as the sectarian allegiance of one of the characters, namely 'İsā b. Hišām, as the parody of a dimwitted and gullible Shii. Furthermore, his study then traces this anti-Shii tendency through the Maqāmat by re-reading famed episodes such as the Madiriyya, Küfiyya, and others through the prism of sectarian polemics. Stewart's work serves as an important reminder that Islamicate intellectual and literary history were deeply intertwined. Their study in the present requires careful attention to the multiple ways texts like the Maqāmāt owe their formation to an intellectual and cultural milieu.

As several scholars of the maqāma form have noted, al-Hamadānī's role in the genesis of the genre was surely great, but his immediate impact is difficult to assess. While al-Hamadānī's Maqāmāt had success in the Islamic West, the status of the work in the East remains more of a puzzle. ${ }^{4}$ One of the reasons for this perhaps is the very fecund literary environment in which alHamadānī himself was an active participant. The fourth-fifth/tenth-eleventh centuries were moments of great experimentation in literary form. Later works of the fifth/eleventh century that are either contemporary with or post-date alHamadānī, such as the Hikāyat Abī l-Qāsim of al-Azdī or the Da'wat al-ațibbä (Physician's Dinner Banquet) of Ibn Buṭlān (d. 458/1066), were doubtless nourished by the same sources and environment that gave rise to the maqāmāt but may not have been directly influenced by al-Hamadānī's work. ${ }^{5}$ What is clear

4 Jaakko Hämeen Anttilla, Maqama:A History of a Genre, Wiesbaden: Harrassowitz, 2002, p. 126 and following.

5 On the former, see Emily Selove, Hikāyat Abī al-Qāsim: A Literary Banquet, Edinburgh: Edinburgh University Press, 2016, p. 16. 
is that one work, the collection of Ibn Nāqìyā (d. 485/1092), manifests a deep familiarity with the Hamadanian maqāma. Some of al-Hamadānīs plots also serve as the basis for episodes within the Hebrew maqāmāt (Book of Tahkemoni) of Judah al-Harīzì (d. 1235), a Jewish author from Toledo who later settled in the Islamic East.

The most profound moment in the history of the maqāma form both East and West, however, was Abū l-Qāsim al-Ḥarīrīs (d. 516/1122) composition of fifty maqāmāt in an attempt to rival and surpass al-Hamadānī's collection. AlḤarīrī did not author his maqāmāt individually but rather as a complete collection. As an author of works on Arabic grammar, al-Harīī produced a maqāma collection that was suited to the culture of commentary and book reading in which he composed. Matthew Keegan's article, "Digressions in the Islamic Archive: al-Harīin's Maqāmāt and the Forgotten Commentary of al-Panğdīhī (d. 584/1188)", addresses the commentary tradition on Harīin's Maqāmāt. Like Stewart's article, Keegan's presents an important vantage from which to consider the relationship between the maquama and Islamicate intellectual history. From the outset Keegan complicates the commonly held belief that the maqa $\bar{a}$ $m \bar{a} t$ are fundamentally subversive texts that challenge the norms of Islamic ilm. His reading of an early commentator on al-Ḥarīrī clearly demonstrates that this was not how all medieval readers considered the matter; commentators saw within al-Harīin's text not subversions of Islamicate norms but rather their affirmation. Even more interesting is that al-Harīî's commentators were in fact finding in his work methods and modes to better appreciate the subtleties of the Islamic archive. Far from the maqāma's being considered a light or diversionary work of literature as opposed to a serious Islamicate intellectual genre, Keegan shows how deeply enmeshed the supposedly independent domains of literature and thought were in the minds of the maqāma's readers.

The transregional circulation of the maqāma following al-Harīî̀'s publication of his Maqāmat in 1104 CE may rank as one of the more dramatic examples of the rise to prominence of a literary form. Already during the author's lifetime, the collection was reproduced by students in authorized editions and circulated to the Islamic West. Al-Harīin's text moved with scholars to al-Andalus and Central Asia to become a common point of textual authority with which students and scholars from across this broad region would grapple and contend.

The textual authority of al-Ḥarīī spawned commentarial activity, translation, and rivalrous emulation. Interestingly, it was at the margins of the circulation of the text that much creative energy was expended in creating rival visions of al-Harīin's collection. Ibn al-Ashtarkūwī (d. 538/1143) authored one of the first and most remarkable recastings of al-Ḥarīì's Maqāmāt. Al-Aštarkūwī's 
Maqāmāt Luzümiyya attests to the ways that texts might produce a poetics of estrangement of space and language. Just as Ibn al-Aštarkūwī nearly doubled the geographic range of al-Harīin by sending characters on fictive voyages from al-Andalus to China, he also broadened the scope of literary play by employing the constrained rhyme scheme of Abū 'Alā' al-Ma'arrī (d. 449/1057).

In "Between Arabic and Persian Traditions: the Maqāmās of Ḥamīd al-Dīn Balhī (d. 559/1164)", Jaakko Hämeen-Anttila provides a glimpse at quite a different case of literary emulation and competition. Balhī frames his collection (completed 551/1156) in conscious competition with his predecessors'writings in the maqāma genre in Arabic, namely al-Hamadānī and al-Ḥarīī. Balhī's work, composed at a moment when Arabic and Persian were competing as languages of communication both in scientific and non-scientific areas, is doubtless related to this complex linguistic landscape. The text, while absorbing many features of Arabic rhetoric and vocabulary, nonetheless places Arabic and Persian as rival signifiers of value. The text's readers were bilingual and sought to demonstrate their capacity as interpreters of both languages and literary traditions. The work draws attention to the border between Arabic and Persian through conscious juxtaposition and blurring (such as in, for instance, macaronic poetry). Hämeen-Anttila points to the fact that this contrast between two languages is unique in Persian works which, while often incorporating quotations from Arabic verse and prose, do not consciously oppose the two languages. The maqāma in Persian literature was surely a popular phenomenon, but its fame was short-lived. While many esteemed the work of Balhī, no writer who followed him attempted to rival his Persian maqāmāt.

Quite analogous with Balhì was the Jewish author Judah al-Harīzì whose Book of Tahkemoni was framed as a direct response to a challenge that no work in Hebrew could compete with the brilliance of al-Harīi's Maqāmāt. In fact, before undertaking this work Harīzì had executed an impressive translation (or perhaps better a "rewriting") of al-Harīī’s Maqāmāt in Hebrew as well as a rhyming prose travelogue in Judeo-Arabic, Kitāb al-Durar (Book of Pearls), which leveled blame for and invective against individuals and communities across the lands of al-Harizìs travels. The Book of Tahkemoni was the most classicizing example of rhymed-prose fiction in Hebrew in that it faithfully mimicked the basic plot features maintained most consistently by al-Harīiñ. Yet it was preceded by other Hebrew works from Islamic and Christian Iberia (where Arabic literature was also esteemed) by authors such as Solomon Ibn Șaqbel and Judah Ibn Šabbetai who blend rhymed prose and metered verse that closely mimic the maqāma's form while reimagining some of its plot contours.

One of the more imaginative collections of Hebrew maqāmāt composed after al-Ḥarīzī is Ya'aqov ben El'azar's (d. Toledo, 1233) Sefer ha-Mešalim (Book 
of Stories/Allegories), a collection of ten episodes some of which closely follow typical maqäma plot structure and some of which diverge from it. Tova Rosen's article, "The Beard as Spectacle and Scandal in a Thirteenth-century Hebrew Maqāma" is a focused reading of one episode that at first closely adheres to a predictable pattern of encounter, verbal display, and anagnorisis but later gives way to a dramatic subversion of the classical maqāma. Rosen focuses on what might at first seem a superfluous element of the plot-the dissembling protagonist's lengthy and unruly beard - to argue, through a reading informed by Mikhail Bakhtin's notions of the "grotesque body", the "carnivalesque", and the "seriocomic", for its centrality as a bearer of symbolic meanings.

The history of the maqāma in Arabic and Hebrew literatures used to be concerned mainly with the so-called Classical periods. In Arabic, this meant the roughly two-hundred-year period from al-Hamadānī to al-Ḥarīī. In Hebrew Literature, studies were confined mainly to the great Iberian authors of the maqāma. One particularly fertile area of interest was the theory of a possible connection between the maqāma in Hebrew and in Arabic literature and the rise of the picaresque novel in sixteenth-century Spain. Leaving aside the large debate about the proof for this development, the undue emphasis on questions of cultural influence has been somewhat blinding. Even in the most positive version of these arguments, the value of the maqäma rests mainly in its being a model or prototype of the Western picaresque novel. Such thinking occludes and elides the long history of the maqāma's circulation across the Islamic world. Moreover, the theses of Iberian exceptionalism which often accompanied it make it difficult to see how Arabic and Hebrew texts often share much with less studied literary works from other regions. In the study of Arabic literature, one area of progress has been the realization that the maqāma flourished in the centuries following al-Harīī. Such a perspective helps dispel the common preconception that Arabic literature suffered a period of great decline after 1200, a thesis that has been assumed all too often for other areas of Islamicate intellectual production. Similarly, the field of Hebrew literature has focused on authors of medieval Iberia imagined as belonging to a "Golden Age" that prefigured the emancipation of Jews in modern Europe, and hence scholars have left the Hebrew maqūma's later incarnations relatively neglected. Rather than being a phenomenon necessarily typified by region, the maqāma (and for that matter Arabic and Hebrew literatures) was a transregional literary phenomenon.

Maurice Pomerantz's article "A Maqāma on Same-sex Marriage from the Thirteenth Century" examines how a leading author al-Šābb al-Ẓarīf alTilimsānī employs the maqāma form in ways that underscore imbalances of power and language. This article, which contains the editio princeps of this 
work, describes how the maqāma comments on and disrupts power relations that are constructed and secured through language. In this maqāma the narrator, a pimp, records the clever play of a trickster ephebe who turns from the passive beloved to the active penetrator of his more powerful Mamluk lover. Money, too, plays an important role in the maqāma as it betrays the uncomfortable similarities between marriage and prostitution and the legal devices by which brides might subvert the formal legal system in order to obtain bridal gifts from their spouses. Finally, the imaginary marriage contract which is at the center of the maqäma violates not only the notion of marriage which was exclusively defined as occurring between a man and woman but also violates the lofty rhetoric of these contracts through its employment of rare dialectical words. This thirteenth-century maqāma stands as a witness to the numerous maqāmas that address diverse topics and have yet to be edited and studied by scholars.

Adena Tannenbaum's article, "Hidden Gems: The Hebrew Maqāma from Yemen," similarly explores much terra incognita. Tannenbaum notes that the Yemenite maqāmas has assumed a far less important role in scholarship on Hebrew literature than Iberian creations noting Eurocentrism, the absence of a Hebrew press in Yemen, and the loss of Yemenite manuscripts in the course of the migration of Jews to Israel in 1949-1950 as reasons for this underrepresentation. Her article focuses on what she terms the "richest, most colorful, and complex" of the Hebrew maqäma collections from Yemen, Zekhariah alDāhirīs Sefer ha-musar (best translated as the Book of Adab). Tannenbaum's article shows that al-Ḍāhirī drew widely from diverse sources including alHamadānīi and al-Harīīī, al-Ḥarīzì's Taḥkemoni, and Immanuel of Rome's Maḥberot (a brilliant achievement by a contemporary and reader of Dante). Moreover, the work enframes and reworks many existing genres including folk tales, homilies, poems, letters, riddles, travelogues, dialogues, debates, and mystical writings and as such is a poignant testimony to Jewish intellectual culture in Yemen writ large.

The concluding article in this volume by Max Shmookler, "Each Nail a Jail': Kitāb al-Masāmìr as Contemporary Critique," focuses on the nine maqāmāt authored by the Alexandrian 'Abdallāh al-Nadīm (d. 1896) entitled the "Book of Nails" (Kitāb al-Masāmīr). Shmookler's essay argues that modern critics have often misjudged and overlooked the works of the maqāma genre composed during the latter half of the nineteenth century. His careful contextualization of al-Nadīm's Masämìr within the famed debates of the late nineteenth century shows that the maqāma was not "out of step" with a burgeoning Arab literary modernity. Shmookler attends not only to the aesthetics of these texts (placing them within a long tradition of antecedent literature) but also sees within 
them a vibrancy that spoke to the present circumstances of the late Ottoman period. Rather than antiquarian set pieces, the maqāma becomes a vital form of its own which suggests that alternative histories of the nahda may be forthcoming from a new generation of scholars. 